\author{
(online) $=$ ISSN $2285-3642$ \\ ISSN-L = $2285-3642$ \\ Journal of Economic Development, Environment and People \\ Volume 2, Issue 1, 2013 \\ URL: http://jedep.spiruharet.ro \\ e-mail: office jedep@spiruharet.ro
}

\title{
The analysis of the energy intensity of economies by selected indicators of sustainability (Rio+ 20) ${ }^{1}$
}

\author{
Peter Adamišin, Emília Huttmanová \\ University of Prešov in Prešov, Faculty of Management, Department of environmental management, \\ 17. novembra 1, 08001 Prešov
}

\begin{abstract}
The aim of this paper is to analyze the status and the development of energy intensity in selected countries of Central and South-eastern Europe. Reducing of energy consumption is one of the ways to ensure not only economic, but also environmental aspects of sustainability.

This paper describes the relationship between economic development and energy intensity of countries, particularly the countries of the selected region.
\end{abstract}

Keywords: energy intensity, primary energy consumption, GDP, national economy

JEL Codes: Q01, R11

\section{Introduction}

One of the questions, which the United Nations Conference on Sustainable Development Rio $20+$ dealt with, was the question of higher utilization of renewable energy sources.

Renewable energy, with support of economic growth, could significantly reduce carbon emissions and pollution in outdoor and indoor spaces. (The Future we want, 2012)

\footnotetext{
${ }^{1}$ This article is published as one of the outputs of the grant No. APVV- 20-060805, APVV LPP-0211-09, KEGA 384001PU-4/2010, VEGA 1/0541/11 and KEGA 007PU-4/2011
} 


\author{
(online) = ISSN $2285-3642$ \\ ISSN-L = $2285-3642$ \\ Journal of Economic Development, Environment and People \\ Volume 2, Issue 1, 2013 \\ URL: http://jedep.spiruharet.ro \\ e-mail: office jedep@spiruharet.ro
}

Various climate scenarios predict raising the temperature of climate over the next 100 years up to 3 ${ }^{\circ} \mathrm{C}$. According to these forecasts, there would be a rapid melting of glaciers in the Antarctic, the Arctic and Greenland, which would cause increasing the global sea levels and flooding of densely inhabited areas, particularly in India, Bangladesh, but also in Europe. Currently, there is an acceleration of melting glaciers. At the national conference UNO in Rio de Janeiro in 1992, which was oriented to environment and sustainable development, was adopted the United Nations Framework Convention on Climate Change, which is a main legal tool for the global climate protection. Problems with the enormous growth of all types of environmental pollution are currently transferred to Asian countries, especially to highly populated areas in China and India. Economies of these countries are developing rapidly, but there are not contracts or agreements oriented to reducing emissions (Barančíková, G., Fazekašová, D., Manko, P., Torma, S., 2009, s.173).

There are renewable natural resources usable as energy: sun, water, wind, and biomass. The potential of renewable energy sources is used around 25\% in the Slovak Republic (Hronec et al, 2009, s.150).

The issue of more intensive use of renewable energy sources is the topic of many other authors (Milošev et al, 2011; Golušin, Ivanovič, Vučenov, 2012; Matovska, Siljanovska, 2012 and others).

The more intensive use of renewable energy sources leads to cleaner production. Cleaner production is characterized as the systematic and purposeful application of strategies for the prevention of environmental pollution, focused on processes, products and services with the main aim to increase their efficiency and to reduce risks to humans and the environment. Consistent application of cleaner production affects all phases of the reproductive process and is oriented to reducing of environmental impacts. In practice, cleaner production is applying by solution of partial problems in technology characterized by important impact to environmental pollution (Chovancová, 2011, s.84).

Realization of renewable energy sources projects is one of the groups of environmental projects. On the basis of demonstrated differences of environmental projects in comparison with conventional commercial project, we can conclude that the financing of environmental activities is characterized by following specifics:

- low or no economic return of projects based (mainly or exclusively) on environmental activities

- low interest of entrepreneurs in the realization of environmental activities,

- pressure of government authorities to entrepreneurs to environmental activities support and their realization, mainly by legislative standards

- specificity in assessing of the economic benefits raised from environmental activities - benefits in reduction of fines and payment due to lower environmental damages after the realization of environmental project

- significantly more social than economic character of realization of environmental activities

- the result is often, in the eyes of the public, improved perception of economic activities of entrepreneur, in the comparison with PR activities (Kotulič, Závarská, 2007, s. 5) 


\author{
(online) = ISSN $2285-3642$ \\ ISSN-L = $2285-3642$ \\ Journal of Economic Development, Environment and People \\ Volume 2, Issue 1, 2013 \\ URL: http://jedep.spiruharet.ro \\ e-mail: office jedep@spiruharet.ro
}

We can conclude that the increased use of renewable energy sources cannot do in the current technological conditions without simulative external environment (especially financial support). An alternative to the environmentally efficient use of energy can be a more efficient use of technologies based on conventional energy consumption, thus the continuous improvement of technological processes in the activities of national economies.

\title{
2. Methodology
}

In the present contribution we analyze the status and development of renewable energy sources in the selected EU countries with a focus on the countries of Central and Southeastern Europe.

We use a set of selected indicators of sustainable development (in the category Climate change and energy, used also by Eurostat), which is also in accordance with the strategy Europe 2020. We complement the global economic indicators into the analysis.

The analysis includes the period 2001-2010.

There are assessed indicators: GDP per capita in EUR, indicators of sustainable development: Primary energy consumption in tones of oil equivalent (TOE) respectively in 1000 tones of oil equivalent (TOE)

Data for the analysis were obtained from official sources of Eurostat.

In the analysis, we focused mainly on the status and development of selected indicators in those countries which are members of ACEU. Unfortunately, due to the absence of relevant data, analysis could not be realized in all members' countries.

We are focused on countries of Central and Southeastern Europe: Bulgaria, Hungary, Romania, Slovak Republic and Slovenia.

The data were processed by statistical software Statistica and Systat.

There was realized normality test of analyzed values, considering sample size, by Shapiro-Wilk test ${ }^{2}$.

$$
\mathrm{W}=\frac{\left(\sum_{\mathrm{i}=1}^{\mathrm{n}} \mathrm{a}_{\mathrm{i}} \mathrm{x}_{(\mathrm{i})}\right)^{2}}{\sum_{\mathrm{i}=1}^{\mathrm{n}}\left(\mathrm{x}_{\mathrm{i}}-\overline{\mathrm{x}}\right)^{2}},
$$

$x(i)$ - the ith-smallest number in the sample

$\bar{x}$ - the sample mean

ai - the constants $a_{i}$ are given by

\footnotetext{
${ }^{2}$ http://www.vniuk.co.uk/products/imsl/imsl/v30/api/com/imsl/stat/NormalityTest.html
} 


$$
\begin{gathered}
\text { (online) }=\text { ISSN } 2285-3642 \\
\text { ISSN-L }=2285-3642
\end{gathered}
$$

Journal of Economic Development, Environment and People

Volume 2, Issue 1, 2013

URL: http://jedep.spiruharet.ro

e-mail: office jedep@spiruharet.ro

$$
\left(a_{1}, a_{2}, \ldots a_{n}\right)=\frac{m^{T} V^{-1}}{\left(m^{T} V^{-1} V^{-1} m\right)^{1 / 2}}
$$

$m=\left(m_{1}, m_{2}, \ldots m_{n}\right)^{\top}$,

$\mathrm{m}_{\mathrm{i}}$ - the expected values of the order statistics of an iid sample from the standard normal distribution $\mathrm{V}$ - the covariance matrix of those order statistics.

Correlation analysis in case of rejection of normality was realized by Kendall tau coefficient:

$$
\tau_{\mathrm{B}}=\frac{\mathrm{n}_{\mathrm{c}}-\mathrm{n}_{\mathrm{d}}}{\sqrt{\left(\mathrm{n}_{0}-\mathrm{n}_{1}\right)\left(\mathrm{n}_{0}-\mathrm{n}_{2}\right)}}
$$

$\mathrm{n}_{0}=\mathrm{n}(\mathrm{n}-1) / 2$

$\mathrm{n}_{1}=\sum_{i} t_{i}\left(t_{i}-1\right) / 2$

$\mathrm{n}_{2}=\sum_{j} u_{j}\left(u_{j}-1\right) / 2$

$n_{c}$ - number of concordant pairs (i.e. if $x_{i}>x_{j}$ a $y_{i}>y_{j}$ or $x_{i}<x_{j}$ a $y_{i}<y_{j}$ for each sample consisting of $n$ observations pair of variables $X$ and $Y$ )

$n_{d}$ - number of discordant pairs (i.e. if ak $x_{i}>x_{j}$ a $y_{i}<y_{j}$ or $x_{i}<x_{j}$ a $y_{i}>y_{j}$ )

$\mathrm{t}_{\mathrm{i}}$ - number of tied values the $\mathrm{i}^{\text {th }}$ group of ties for the first quantity

$u_{j}$ - number of tied values the $j^{\text {th }}$ group of ties for the second quantity

\section{Results and Discussion}

We assessed the relationship between economic development and consumption of energy.

Economic development was assessed by the indicator of production - GDP per capita in millions EUR in current prices, average of the period 2001-2010. We assessed the energy consumption by indicator Primary energy consumption in tonnes of oil equivalent (TOE) per capita and by indicator Primary energy consumption in 1000 tonnes of oil equivalent (TOE) to GDP in millions EUR.

Because the normality test leads to the rejection of preconditions about normal distribution of analyzed values, the correlation test was Kendall test.

Tab. 1: Results of correlation analysis

\begin{tabular}{r|r|r|r|}
\hline & energy/GDP & energy_per_capita & GDP_per_capita \\
\hline energy/GDP & 1,000 & $-0,269 *(0,027)$ & $-0,610 * *(0,000)$ \\
\hline energy_per_capita & $-0,269 *(0,027)$ & 1,000 & $0,644 * *(0,000)$ \\
\hline GDP_per_capita & $-0,610 * *(0,000)$ & $0,644 * *(0,000)$ & 1,000 \\
\hline
\end{tabular}




\author{
(online) = ISSN $2285-3642$ \\ ISSN-L = $2285-3642$ \\ Journal of Economic Development, Environment and People \\ Volume 2, Issue 1, 2013 \\ URL: http://jedep.spiruharet.ro \\ e-mail: office jedep@spiruharet.ro
}

Based on the results of the analysis, we can conclude that there is a highly significant correlation between the parameters. Between the economic development in the countries (economic indicator) and both indicators of energy consumption, there is highly reliable and close causal relationship. High production of GDP per capita in the country also indicates high energy consumption per capita. In this case, there is causation - high economic development in the country or welfare of country allows to inhabitants to achieve a higher level of satisfaction of their needs, which are often related with the consumption of energy resources. However, the analysis also pointed out to another important (and statistically significant) relationship - higher output GDP per capita in the country is in indirect relation to the energy consumption per unit of GDP. Thus, countries more advanced economically - more developed countries, are able to produce their outputs and income more energy efficiently - per unit of GDP they consume less energy than economically less developed countries. It relates to the structure of the economies of more and less developed countries. In the economically more developed countries, there is a gradual transition to a more sophisticated sectors, not only in industry (with a lower consumption of resources, including energy consumption), but also to higher level of development of the tertiary and quaternary sectors of national economy.

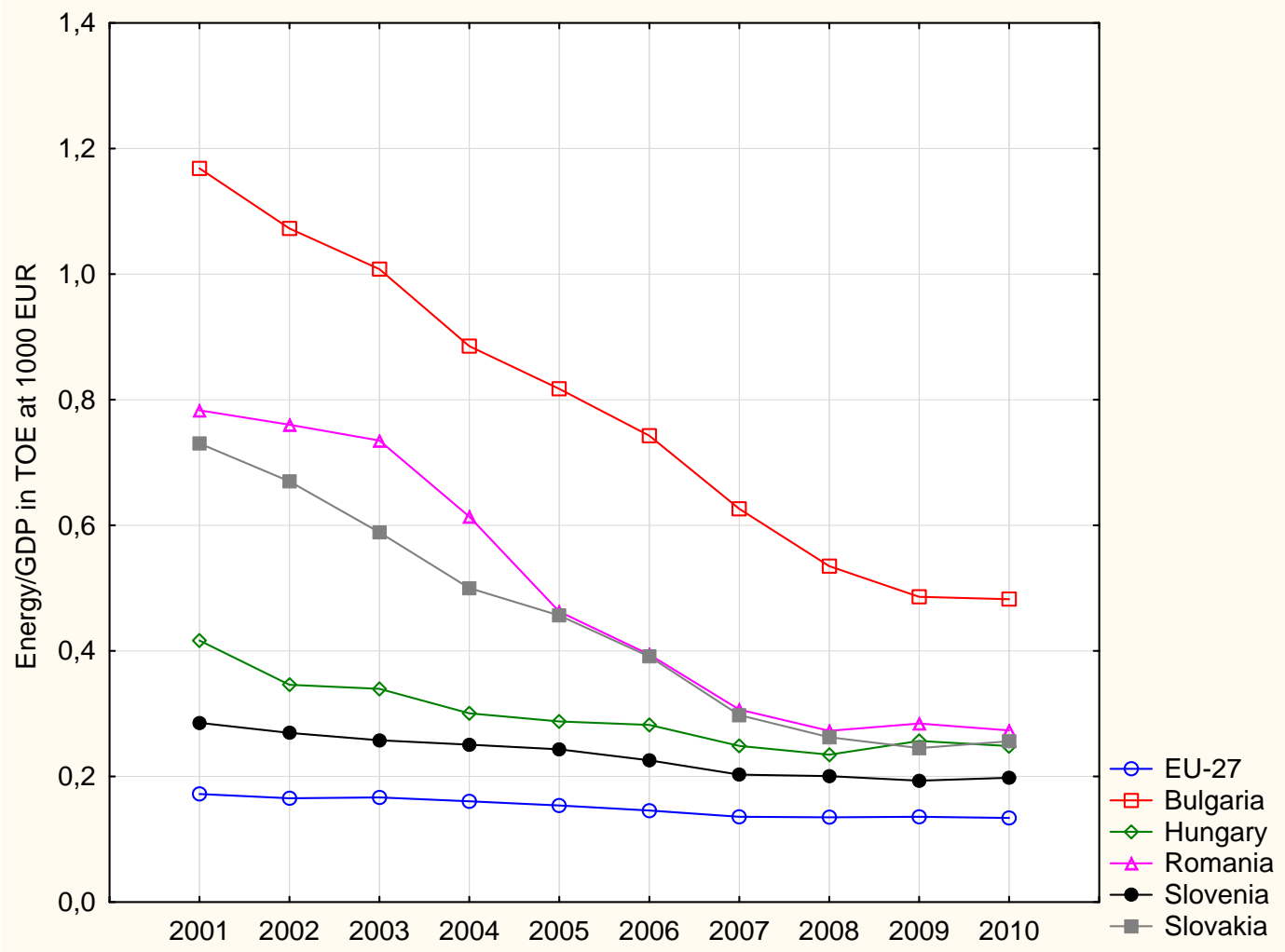

Fig. 1: Annual change of energy consumption in the selected countries (in TOE/1000 EUR) 


\author{
(online) = ISSN $2285-3642$ \\ ISSN-L = $2285-3642$ \\ Journal of Economic Development, Environment and People \\ Volume 2, Issue 1, 2013 \\ URL: http://jedep.spiruharet.ro \\ e-mail: office jedep@spiruharet.ro
}

Even though economically less developed countries have significantly higher energy consumption to GDP production. We can observe a significant decrease in the energy intensity of these economies over the past 10 years. Although still we cannot concluded, that the transitive countries are with their level of energy intensive of GDP, at the level of EU countries average, in several cases there were even a multiple reduction in energy intensity. It is due to both higher annual increase of GDP in these countries (opposite to economically more advanced countries of the EU), as well as the ongoing restructuring of economies in favor of less energy intensive activities and sectors.

In the time series analysis oriented to modeling of possible future development of energy intensity of economies it is possible to use linear regression models. There were calculated highly significant models (in the model as a whole, as well as in the regression parameters) in each country.

Assuming that the energy consumption is changed, the effect of time is significant (technological changes, continuous process of restructuring economies is realized in time). In this case will be time only one dependent variable.

regression model of $\mathrm{EU}-27$ :

$\mathrm{y}^{* *}=0,1769 * *-0,0048 * * \mathrm{x}$

regression model of Bulgaria:

$\mathrm{y}^{* *}=1,2325^{* *}-0,0818^{* *} \mathrm{x}$

regression model of Hungary

$\mathrm{y}^{* *}=0,3904^{* *}-0,0171^{* *} \mathrm{x}$

regression model of Romania:

$\mathrm{y}^{* *}=0,8626^{* *}-0,06799 * * \mathrm{x}$

regression model of Slovenia:

$\mathrm{y}^{* *}=0,2915^{* *}-0,0107^{* *} \mathrm{x}$

regression model of Slovak republic:

$\mathrm{y}^{* *}=0,7581^{* *}-0,0578^{* *} \mathrm{x}$

There is a prediction of development modelled based on the linear regression models given in table 2.

Table 2: Model values of energy consumption, including prediction

\begin{tabular}{|c|c|c|c|c|c|c|}
\hline & EU -27 & Bulgaria & Hungary & Romania & Slovenia & Slovakia \\
\hline 2001 & 0,1721 & 1,1507 & 0,3732 & 0,7946 & 0,2809 & 0,7002 \\
\hline 2002 & 0,1673 & 1,0689 & 0,3561 & 0,7266 & 0,2702 & 0,6424 \\
\hline 2003 & 0,1625 & 0,9871 & 0,3390 & 0,6586 & 0,2595 & 0,5845 \\
\hline 2004 & 0,1577 & 0,9052 & 0,3219 & 0,5906 & 0,2488 & 0,5267 \\
\hline 2005 & 0,1529 & 0,8234 & 0,3047 & 0,5226 & 0,2381 & 0,4689 \\
\hline 2006 & 0,1482 & 0,7416 & 0,2876 & 0,4546 & 0,2275 & 0,4110 \\
\hline
\end{tabular}




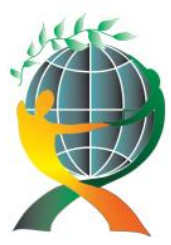

$$
\begin{gathered}
\text { (online) }=\text { ISSN } 2285-3642 \\
\text { ISSN-L }=2285-3642
\end{gathered}
$$

Journal of Economic Development, Environment and People

Volume 2, Issue 1, 2013

URL: http://jedep.spiruharet.ro

e-mail: office jedep@spiruharet.ro

\begin{tabular}{|l|l|l|l|l|l|l|}
\hline 2007 & 0,1434 & 0,6598 & 0,2705 & 0,3866 & 0,2168 & 0,3532 \\
\hline 2008 & 0,1386 & 0,5780 & 0,2534 & 0,3186 & 0,2061 & 0,2953 \\
\hline 2009 & 0,1338 & 0,4962 & 0,2362 & 0,2506 & 0,1954 & 0,2375 \\
\hline 2010 & 0,1290 & 0,4144 & 0,2191 & 0,1826 & 0,1847 & 0,1797 \\
\hline 2011 & 0,1242 & 0,3326 & 0,2020 & 0,1146 & 0,1741 & 0,1218 \\
\hline 2012 & 0,1194 & 0,2507 & 0,1849 & 0,0466 & 0,1634 & 0,0640 \\
\hline 2013 & 0,1146 & 0,1689 & 0,1677 & $-0,0214$ & 0,1527 & 0,0061 \\
\hline 2014 & 0,1098 & 0,0871 & 0,1506 & $-0,0894$ & 0,1420 & $-0,0517$ \\
\hline
\end{tabular}

Based on the predictions of the development of energy consumption based on the acceptance obtained regression models, it is possible to assume, that analyzed countries will achieve level of the energy intensity of EU countries, in the next few years. This statement cannot be unequivocally accepted, it is necessary to remember, that it is prediction of the future development only based on the only one dependent variable. We can see a trend of continuous reduction of the energy intensity of economies in transition countries and its convergence to average of EU countries. Most probably, the average values of EU countries will not be achieved in any of the analyzed countries in the next few years.

\section{Conclusions}

One of the ways of sustainability ensuring in the context of the conclusions of the Rio +20 , is searching for more energy-efficient ways of GDP producing. In this paper, we analyzed the energy consumption of selected economies of Central and Southeastern Europe. We can make conclusion that there is a highly significant relationship between economic development and energy consumption, as well as there is relationship between the sophistication of countries and energy-efficient producing of GDP. Transitive countries of Central and Southeast Europe do not attain average of EU countries, but their energy intensity has been improved, in 10 last years. This is one of the ways to ensure of sustainability, higher energy self-sufficiency and better environment of these countries, except for the use of renewable energy sources, in the relation to the conclusion of Rio $20+$.

\section{References}

[1] Barančíková, G., Fazekašová, D., Manko, P., Torma, S. 2009. Chémia životného prostredia. Prešov: Prešovská univerzita v Prešove, 2009. 225 p. ISBN 978-80-555-0082-9

[2] Bednárová, L., Liberko, I. 2009. Environmental benchmarking and benefit of perfomance benchamarking. In Intercathedra : annual scientific bulletin of plant - economic department of the European wood technology university studies. no. 25 (2009), p. 161-163. ISSN 1640-3622

[3] Golušin, M., Ivanovič, O., M., Vučenov, S. 2012. Sustainable energy management - a prerequisite for the realization Kyuto Protocol. In Journal of Economic Development, Environment and People. no. 1 (2011), p. 27- 


\author{
(online) = ISSN $2285-3642$ \\ ISSN-L = $2285-3642$ \\ Journal of Economic Development, Environment and People \\ Volume 2, Issue 1, 2013 \\ URL: http://jedep.spiruharet.ro \\ e-mail: office jedep@spiruharet.ro
}

34. ISSN $2285-3642$

[4] Hronec, O. et al. 2009. Manažment a oceňovanie prírodných zdrojov. Skalica : Stredoeurópska vysoká škola, 2010. 202 p. ISBN 978-88-89391-19-6.

[5] Chovancová, J. 2011. Systémy environmentálneho manažérstva. Prešov : Prešovská univerzita v Prešove, 2011. 98 p. ISBN 978-80-555-0485-8

[6] Kotulič, R., Závarská, Z. 2007. Špecifiká financovania environmentálnych aktivít. MendelNET 2007: sborník příspěvků z konference studentů doktorského studia. Brno : Mendelova zemědělská a lesnická univerzita, 2007. ISBN 978-80-903966-6-1

[7] Matovska, M., Siljanovska, Z. 2012. Investments in Sustainable Development of Renewable Energies in the Republic of Macedonia. In CCEDEP 2012. 2nd climate change, economic development, environment and people conference. Prešov: Vydavatel'stvo Prešovskej univerzity, 2012. p. 216-221. ISBN 978-80-555-0607-4

[8] Melišová - Č., M., Drozda, J., Rovňák, M., 2012. Environmental security in company. In Proceedings of the International scientific correspondence conference EAEP 2012. Prešov : Prešovská univerzita v Prešove, 2012. S. 159-165. ISBN 978-80-555-0655-5

[9] Milošev, I., Mijušković, L., Abramović, G., Katić, A., Brkanlić, S. 2011. Energy potential of Republic of Serbia as an Investment Opportunity. In Journal of Economic Development, Environment and People. no. 1 (2011), p. 23-30. ISSN 2285 - 3642

[10] Tej, J. 2008. Regionálny manažment - strategická forma partnerstva pri dosahovaní vyššej regionálnej konkurencieschopnosti. In Konkurencieschopnost' a regionálny rozvoj. Košice : Technická univerzita v Košiciach, Ekonomická fakulta, 2008. p. 49-171. ISBN 978-80-553-0111-2

[11] The Future we want. 2012. Konferencia OSN o trvalo udržatel'nom rozvoji Rio 20+. 2012. Available at: http://www1.enviroportal.sk/images/indikatory/0000/33/Rio+20.pdf 


$$
\begin{gathered}
\text { (online) }=\text { ISSN } 2285-3642 \\
\text { ISSN-L }=2285-3642
\end{gathered}
$$

Journal of Economic Development, Environment and People

Volume 2, Issue 1, 2013

URL: http://jedep.spiruharet.ro

e-mail: office jedep@spiruharet.ro

Appendix

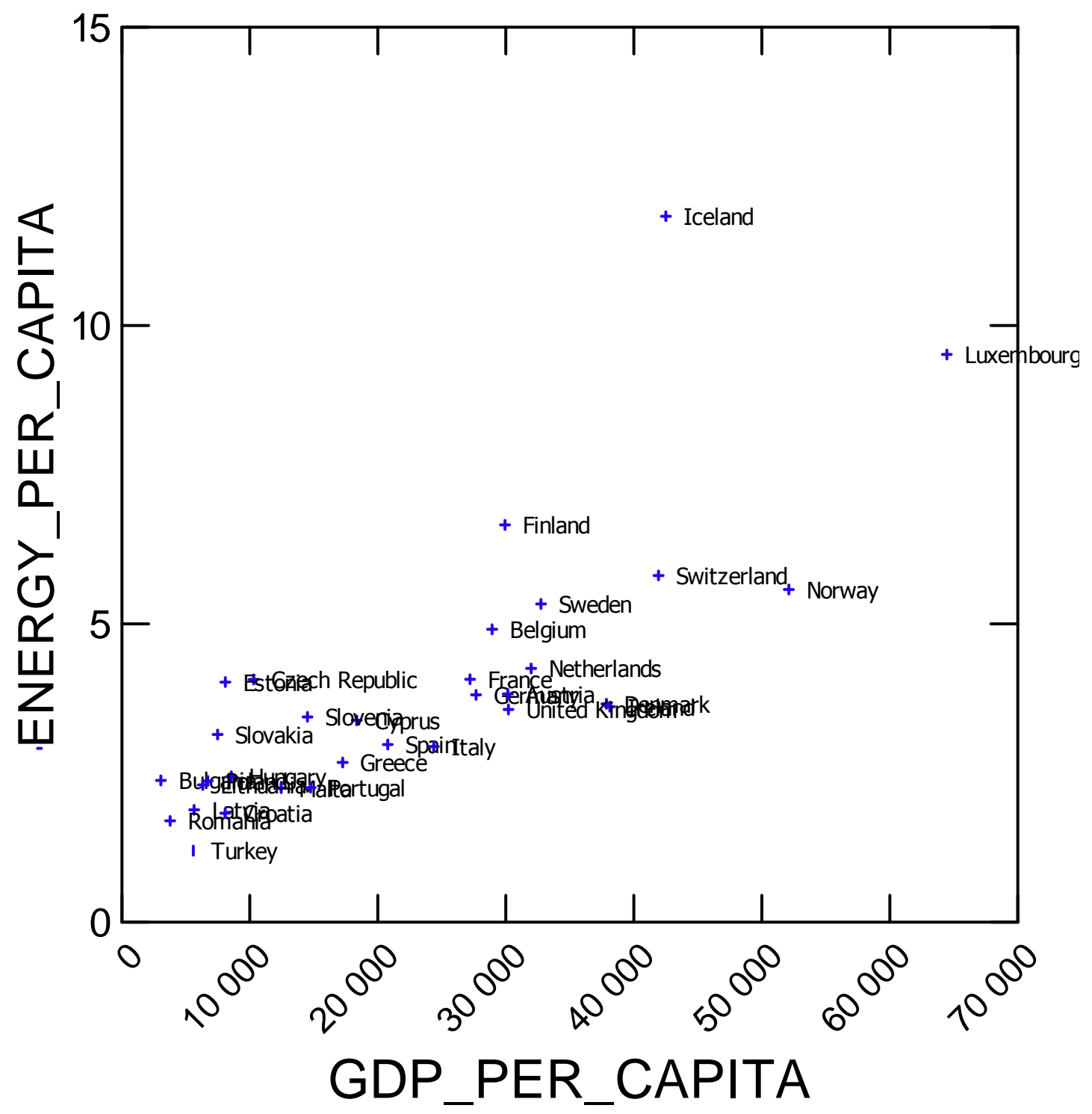

Fig. 1: Relationship between GDP per capita and energy consumption per capita in the selected countries. 


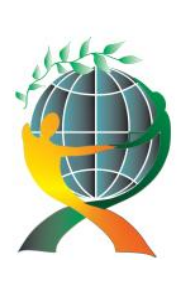

$$
\begin{gathered}
\text { (online) }=\text { ISSN } 2285-3642 \\
\text { ISSN-L }=2285-3642
\end{gathered}
$$

Journal of Economic Development, Environment and People

Volume 2, Issue 1, 2013

URL: http://jedep.spiruharet.ro

e-mail: office jedep@spiruharet.ro

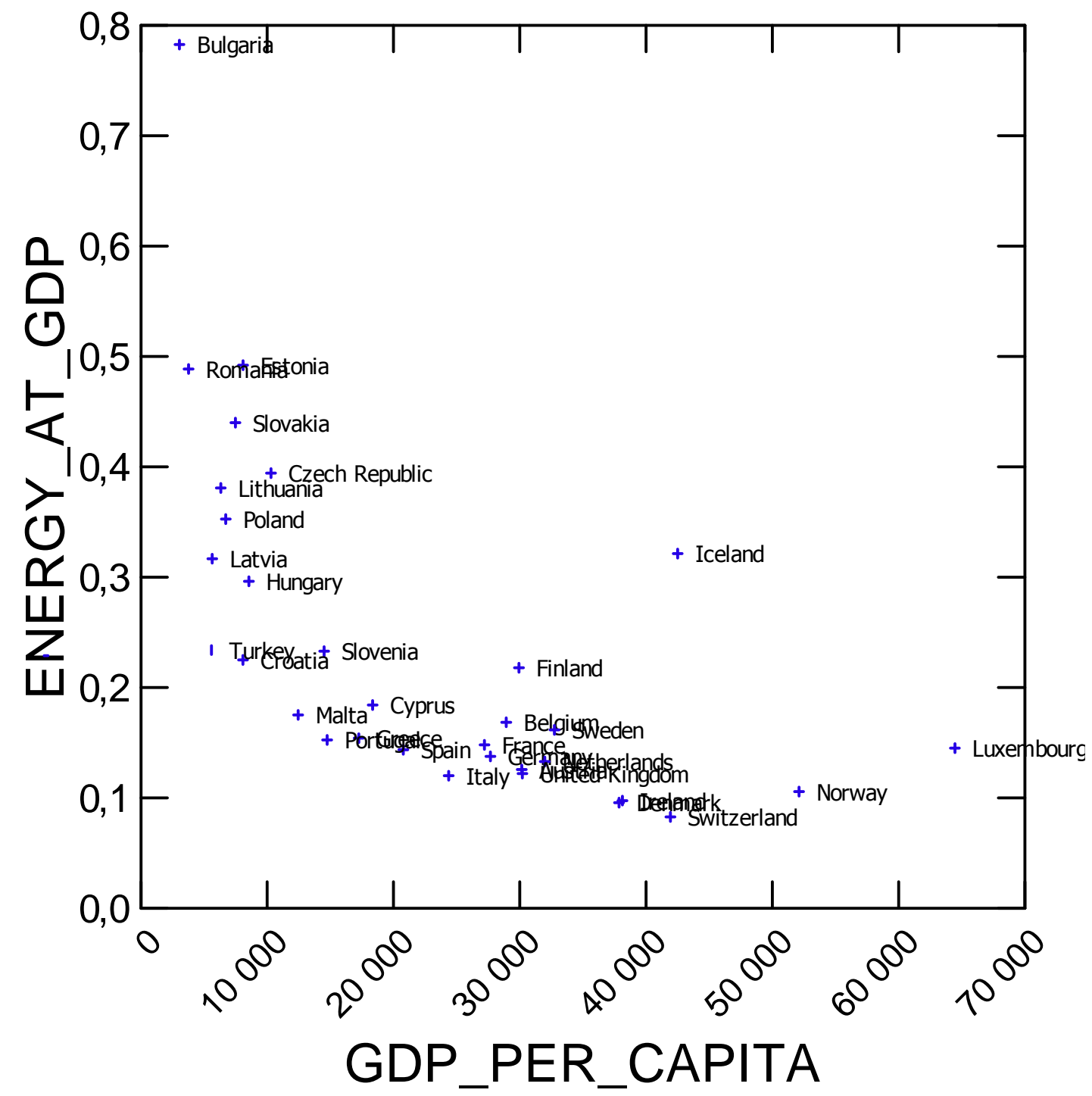

Fig. 2: Relationship between GDP per capita and energy consumption per unit of GDP in the selected countries. 